\title{
PENGARUH PENAMBAHAN OMAFAC IMPROVED DALAM RANSUM AYAM TERHADAP PRODUKSI DAN KUALITAS TELUR')
}

gunakan tujuan u penamb: pakan, telur, ko Unit Hal

Tabel 1

\author{
Muhammad Kamal2 ${ }^{2}$ )
}

PENDAHLLUAN

ABSTRAK
Penelitian ini bertujuan untuk mengetahui manfaat penambahan Omafac Improved (OI) ke dalam ransum bila ditinjau dari : konsumsi pakan, berat telur, jumlah produksi telur, berat produksi telur, konversi pakan, tebal kerabang. nilai warna yolk dan Unit Haugh.

Dengan Rancangan Blok Acak Lengkap (RCBD) ayam sebanyak 168 ekor dibagi menjadi 3 blok kandang masing-masing terdiri dari 56 ekor. Setiap blok kandang terdiri dari 7 kandang kelompok untuk perlakuan ransum yang masing-masing berisi 8 ekor ayam.

Dari satu ransum basal dengan $17,65 \%$ Protein Kasar (PK), $2632 \mathrm{kcal}$ Energi Termetabolis (ME) $/ \mathrm{kg}, 2,60 \% \mathrm{Ca}$ dan $0,69 \% \mathrm{P}$ dibuat 7 ransum perlakuan yang masing-masing dibedakan pada adanya penambahan OI, yaitu ransum $\mathrm{R}_{1}$ (ransum basal tanpa $\mathrm{OI}$ ), ransum $\mathrm{R}_{2}\left(\mathrm{R}_{1}+0,05 \% \mathrm{OI}\right.$ ), ransum $\mathrm{R}_{3}\left(\mathrm{R}_{1}+0,10 \%\right.$ OI), ransum $\mathrm{R}_{4}\left(\mathrm{R}_{1}+0,15 \%\right.$ OI), ransum $\mathrm{R}_{5}\left(\mathrm{R}_{1}+0.20 \% \mathrm{OI}\right)$, ransum $\mathrm{R}_{6}\left(\mathrm{R}_{1}+0,25 \% \mathrm{OI}\right)$ dan ransum $R_{\mathcal{T}}\left(R_{1}+0,30 \%\right.$ OI).

Hasil penelitian menunjukkan bahwa penambahan $0,05 \%-0,30 \%$ ke dalam ransum ayam petelur, ternyata tetap dapat mempertahankan : konsumsi pakan, tebal kerabang dan nilai warna yolk, tetapi cenderung adanya kenaikkan pada berat telur dan Unit Haugh. Di samping itu nampak adanya perbaikan pada : produksi telur, berat telur dan konversi pakan $(\mathrm{P}<0,01)$.

1). Penelitian dibiayai oleh PT. Squibb Indonesia, Jakana.

2). Staf pengajar Jurusan Nutrisi dan Makanan Temak. Fak. Peternakan UGM.
Dalam usaha peternakan ayam diperlukan ransum yang sesuai dengan kebutuhan ayam agar diperoleh hasil yang optimal. Hal ini sehubungan dengan biaya untuk ransum yang cukup tinggi yaitu antara $60-70 \%$ dari biaya produksi

Adanya pabrik makanan ternak yang memproduksi makanan komersial memang besar andilnya dalam membantu berkembangnya usaha peternakan ayam. Tetapi penggunaan makanan komersial dalam suatu usaha peternakan ayam dalam keadaan tertentu cenderung dapat menaikkan biaya makanan bila dibandingkan dengan menggunakan makanan buatan sendiri. Namun untuk membuat ransum yang serasi harus tersedia berbagai bahan pakan penyusun ransum yang baik.

Ransum yang disusun dari bahan pakan alamiah yang berasal dari hewan dan tumbuh-tumbuhan ada kalanya sudah cukup mengandung berbagai nutrien yang diperlukan ternak pada kondisi tertentu, misalnya untuk hidup-pokok. Bagi ternak yang sedang berproduksi, sering menderita kekurangan satu atau beberapa macam nutren, misalnya : asam amino, vitamin ataupun mineral. Untuk itu agar didapat ransum yang serasi yang dapat menaikkan produksi dan kualitas telur periu ditambahkan bahan pelengkap yang biasa dikenal dengan nama feed supplement atau premix (Ewing, 1951).

Salah satu bahan pelengkap tersebut adalah Omafac improved (OI) yang dikemas oleh PT. Squibb Indonesia, yang mengandung berbagai macam asam amino, vitamin dan mineral (tabel I). Ransum yang kekurangan asam amino akan dapat mengakibatkan turunnya produksi telur (NRC., 1977). Beberapa faktor yang mempengaruhi besarnya produksi telur antara lain cukup tidaknya protein dan asam amino dalam ransum tersebut. Di samping itu berbagai macam vitamin dan mineral mempunyai peranan dalam hubungannya dengan produksi telur (Anggorodi. 1979 ).
Kandun

Alanina

Arginina

Asam as

Sistina

Asam glt

Glisina

Histidina

Isoleusin

Leusina

Lisina

Metionin

Fenilalan

Prolina

Serina

Treonina

Triptofan

Tirosina

Valina

Sumber :

Laborato

nakan UG

strain Dek

De

menjadi 3

Setiap blo

perlakuan

$\mathrm{R}_{1}=\operatorname{Rar}$

$\mathrm{R}_{2}=\mathrm{Rar}$

$\mathrm{R}_{3}=\mathrm{Rar}$

$\mathrm{R}_{4}=\mathrm{Rar}$

$\mathrm{R}_{5}=\operatorname{Ran}$

$\mathrm{R}_{6}=\mathrm{Ran}$

$\mathrm{R}_{7}=\operatorname{Rar}$ 
Berdasarkan hal tersebut penelitian dengan menggunakan $\mathrm{OI}$ dalam ransum ayam petelur dilakukan dengan tujuan untuk mengetahui sampai seberapa besar manfaat penambahan OI dalam ransum bila ditinjau dari konsumsi pakan, berat telur, jumlah produksi telur, berat produksi telur, konversi pakan, tebal kerabang. nilai warna yolk dan Unit Haugh.

Tabel 1. Komposisi Omafac improved (OI)

Kandungan asam amino Kandungan vitamin dan mineral $\%$ setiap $\mathrm{kg}$

\begin{tabular}{lllr}
\hline Alanina & 0,71 & $\mathrm{~B}_{1}$ & $4.000 \mathrm{mcg}$ \\
Arginina & 1,30 & $\mathrm{~B}_{2}$ & $23.000 \mathrm{mcg}$ \\
Asam aspartat & 1,20 & $\mathrm{~B}_{6}$ & $12.000 \mathrm{mcg}$ \\
Sistina & 0,50 & $\mathrm{~B}_{12}$ & $2 \mathrm{mcg}$ \\
Asam glutamat & 2,00 & Asam pantoterat & $8.000 \mathrm{mcg}$ \\
Glisina & 2,50 & PP & $50 \mathrm{mcg}$ \\
Histidina & 0,60 & Asam folat & $500 \mathrm{mcg}$ \\
Isoleusina & 1,15 & Biotin & $300 \mathrm{mcg}$ \\
Leusina & 1,80 & E & $20 \mathrm{mcg}$ \\
Lisina & 0,80 & Kolina & $2,000 \mathrm{mcg}$ \\
Metionina & 0,40 & Inositol & $3.000 \mathrm{mcg}$ \\
Fenilalanina & 0,75 & Besi & $240 \mathrm{mcg}$ \\
Prolina & 0,60 & Tembaga & $30 \mathrm{mcg}$ \\
Serina & 0,50 & Mangan & $25 \mathrm{mcg}$ \\
Treonina & 0,90 & Seng & $60 \mathrm{mcg}$ \\
Triptofan & 0,21 & Kobalt & $50 \mathrm{mcg}$ \\
Tirosina & 0,65 & Selenium & $200 \mathrm{mcg}$ \\
Valina & 1,35 & & \\
\hline
\end{tabular}

Sumber: P.T. Squibb Indonesia

\section{MATERI DAN METODE}

Penelitian ini dilaksanakan selama 12 minggu di Laboratorium Nutrisi dan Makanan Ternak Fakultas Peternakan UGM Yogyakarta dengan menggunakan ayam telur strain Dekalb umur 8 bulan sebanyak 168 ekor.

Dengan RCBD, ayam sebanyak 168 ekor dibagi menjadi 3 blok kandang masing-masing terdiri dari 56 ekor. Setiap blok kandang terdiri dari 7 kandang kelompok untuk perlakuan ransum masing-masing berisi 8 ekor ayam.

Tujuan ransum perlakuan terdiri dari :

$\mathrm{R}_{1}=$ Ransum basal, tanpa $\mathrm{OI}$,

$\mathrm{R}_{2}=$ Ransum basal ditambah $0,05 \%$ OI,

$\mathrm{R}_{3}=$ Ransum basal ditambah $0,10 \%$ OI,

$\mathrm{R}_{4}=$ Ransum basal ditambah $0,15 \mathrm{OI}$

$R_{5}=$ Ransum basal ditambah $0,20 \%$ OI,

$\mathrm{R}_{6}=$ Ransum basal ditambah $0,25 \%$ OI,

$\mathrm{R}_{7}=$ Ransum basal ditambah $0,30 \%$ Ol,
Ransum basal tersusun atas $40 \%$ jagung. $30 \%$ bekatul $15 \%$ bungkil kedelai, $7 \%$ tepung ikan, $2,5 \%$ tepung tulang $2,5 \%$ tepung kerang dan $0,5 \%$ garam.

Parameter yang diamati selama 12 minggu adalah :

Konsumsi pakan (gram/ekor/hari), Berat telur (gram/butir) jumlah produksi telur ( $\%$ HDA), rata-rata berat produksi (gram/hari), Konversi pakan, tebal kerabang (Dial Shell thickness, mm), Nilai warna yolk (yolk color fan) dan Unit Haugh $\left(100 \mathrm{~kg} \mathrm{H}+7,57-1,7 \mathrm{~W}^{0,37} ; \mathrm{H}=\mathrm{mm}\right.$, tinggi Albumen $\mathrm{W}=$ gram, berat telur.

Semua data dianalisis dengan Randomized Completely Block Design (RCBD) dan apabila berbeda, analisis dilanjutkan dengan Duncan Multiple Range Test (DMRT) (Gomez dan Gomez, 1984).

\section{HASIL DAN PEMBAHASAN}

\section{Konstimsi pakan}

Konsumsi pakan rata-rata per ekor per hari selama 12 minggu dari ketujuh perlakuan ransum ternyata tidak menunjukkan adanya perbedaan yaitu berkisar dari 120,77 - 124,97 gram/ekor/hari (tabel 2). Dengan demikian maka penggunaan $\mathrm{OI}=(0,05-0,30 \%)$ dalam ransum tidak mengubah jumlah konsumsi pakan bila dibandingkan dengan konsumsi pakan perlakuan tanpa OI.

Tabel 2. Konsumsi pakan ayam strain Dekalb umur 8-11 bulan (gram/ekor/hari)

\begin{tabular}{lcccc}
\hline \multirow{2}{*}{ Perlakuan } & \multicolumn{3}{c}{ B l o k } & Rata-rata \\
\cline { 2 - 4 } & 1 & 2 & 3 & \\
\hline $\mathrm{R}_{1}(0 \%$ OI $)$ & 122,6 & 123,6 & 125,5 & 123,90 \\
$\mathrm{R}_{2}(0,05 \%$ OI $)$ & 122,8 & 124,8 & 123,4 & 123,67 \\
$\mathrm{R}_{3}(0,10 \%$ OI $)$ & 121,1 & 122,7 & 121,4 & 121,73 \\
$\mathrm{R}_{4}(0,15 \%$ OI $)$ & 123,1 & 119,4 & 119,8 & 120,77 \\
$\mathrm{R}_{5}(0,20 \%$ OI $)$ & 122,8 & 123,2 & 119,2 & 121,73 \\
$\mathrm{R}_{6}(0,25 \%$ OI $)$ & 122,7 & 125,8 & 122,4 & 123,63 \\
$\mathrm{R}_{7}(0,30 \%$ OI $)$ & 122,7 & 127,3 & 124,9 & 124,97 \\
\hline
\end{tabular}

\section{Berat telur}

Berat telur rata-rata per butir selama 12 minggu dari ketujuh perlakuan ransum ternyata tidak menunjukkan adanya perbedaan yaitu berkisar dari 59,23 - 61,37 gram/ butir (tabel 3).

Walaupun begitu, penggunaan $\mathrm{Ol}$ dari $0,05-0,30 \%$ ada kecenderungan menaikkan berat telur yaitu yang semula $59,23 \mathrm{gram} /$ butir naik sampai menjadi $61,37 \mathrm{gram} /$ butir. $\mathrm{Hal}$ ini menunjukkan bahwa penggunaan OI dalam ransum cenderung dapat memperbaiki nilai biologis ransum. 
Tabel 3. Berat telur (gram/butir)

\begin{tabular}{lcccc}
\hline \multirow{2}{*}{ Perlakuan } & \multicolumn{3}{c}{ B 1 o k } & \multirow{2}{*}{ Rata-rata } \\
\cline { 2 - 4 } & 1 & 2 & 3 & \\
\hline $\mathrm{R}_{1}(0 \%$ OI $)$ & 58,2 & 58,7 & 60,8 & 59,23 \\
$\mathrm{R}_{2}(0,05 \%$ OI $)$ & 59,3 & 60,3 & 60,3 & 59,97 \\
$\mathrm{R}_{3}(0,10 \%$ OI $)$ & 60,2 & 61,0 & 59,7 & 60,30 \\
$\mathrm{R}_{4}(0,15 \%$ OI $)$ & 61,4 & 60,1 & 60,6 & 60,70 \\
$\mathrm{R}_{5}(0,20 \%$ OI $)$ & 59,9 & 63,1 & 60,4 & 61,13 \\
$\mathrm{R}_{6}(0,25 \%$ OI $)$ & 62,0 & 61,0 & 61,1 & 61,37 \\
$\mathrm{R}_{7}(0,30 \%$ OI $)$ & 60,9 & 61,9 & 60,6 & 61,13 \\
& & & & \\
\hline
\end{tabular}

\section{Produksi telur}

Produksi telur rata-rata per kelompok per hari selama 12 minggu dari ketujuh perlakuan ransum ternyata menunjukkan adanya perbedaan ( $\mathrm{P}<0,01$ ). Semakin tinggi penggunaan OI dari $0,05-0,30 \% 0$ dalam ransum akan semakin tinggi pula produksi telur setiap harinya, yaitu dari $64,52 \%$ naik sampai menjadi $72,30 \%$ (Tabel 4). Walaupun pada penggunaan $\mathrm{Ol}=0,05 \%$ produksi telurnya masih sama dengan pada ransum tanpa OI, namun pada penggunaan OI sebanyak $0,10-0,30 \%$ tampak jelas adanya peningkatan yang menanjak terus. Hasil yang semula $(64,52 \%)$ berada di bawah produksi telur ransum kontrol (Kamal dan Murdhike, 1983) yaitu sebesar $68,75 \%$ ternyata kemudian meningkat sampai melampaui yaitu mencapai $72,30 \%$. Di sini jelas bahwa penggunaan OI sebanyak $0,10 \%-0,309 \%$ dalam ransum akan menaikkan jumlah produksi telur setiap harinya yaitu mulai dari $4,66 \%$ dapat naik terus sampai $12,05 \%$.

Tabel 4. Jumlah produksi telur setiap hari ( $\%$ HDA).

\begin{tabular}{|c|c|c|c|c|c|}
\hline \multirow{2}{*}{ Perlakuan } & \multicolumn{3}{|c|}{ B lok } & \multirow{2}{*}{ Rata-rata } & \multirow{2}{*}{$\begin{array}{c}\text { Naik } \\
(\%)\end{array}$} \\
\hline & 1 & 2 & 3 & & \\
\hline $\mathrm{R}_{1}(0 \%$ OI $)$ & 62,86 & 64,29 & 66,43 & $64,52^{\mathrm{a}}$ & 0 , \\
\hline $\mathrm{R}_{2}(0,05 \%$ OI $)$ & 64,76 & 63,33 & 67.38 & $65,15^{\mathrm{a}}$ & 0.97 \\
\hline $\mathrm{R}_{3}(0,10 \%$ OI $)$ & 67,86 & 66,43 & 68,33 & $67,54 \mathrm{~b}$ & 4,66 \\
\hline $\mathrm{R}_{4}(0,15 \%$ OI $)$ & 67,38 & 69,29 & 70,24 & $68.97 \mathrm{bc}$ & 6,88 \\
\hline $\mathrm{R}_{5}(0,20 \% 0 \mathrm{OI})$ & 68,81 & 70,48 & 69,76 & $69,68^{\mathrm{c}}$ & 7,99 \\
\hline $\mathrm{R}_{6}(0,25 \%$ OI $)$ & 70,95 & 72,38 & 72,86 & $72,06^{d}$ & 11,67 \\
\hline$R_{\uparrow}(0,30 \%$ OI $)$ & 72,62 & 71.19 & 73,10 & $72,30^{d}$ & 12,05 \\
\hline
\end{tabular}

Keterangan : Nilai rata-rata dengan manuskrip yang berlainan menunjukkan adanya perbedaan yang sangat nyata $(P<0,01)$.

\section{Berat produksi telur per hari}

Berat produksi telur rata-rata per ekor per hari selama 12 minggu dari ketujuh ransum perlakuan ternyata menunjukkan adanya perbedaan $(P<0,01)$. Semakin tinggi penggunaan OI dari $0,05-0,30 \%$ dalam ransum akan semakin tinggi pula berat produksi telurnya yaitu dari 38,237 dapat naik sampai menjadi 44,213 gram/ekor/hari (Tabel 5).
Tabel 5. Berat produksi telur (gram/ekor/hari)

\begin{tabular}{|c|c|c|c|c|c|}
\hline \multirow{2}{*}{ Perlakuan } & \multicolumn{3}{|c|}{ B I o k } & \multirow{2}{*}{ Rata-rata } & \multirow{2}{*}{$\begin{array}{c}\text { Naik } \\
\text { (\%) }\end{array}$} \\
\hline & 1 & 2 & 3 & & \\
\hline $\mathrm{R}_{1}(09 \%$ OI $)$ & 36,58 & 37,74 & 40,39 & 38,237 a & 0 \\
\hline $\mathrm{R}_{2}(0.05 \%$ OI $)$ & 38,40 & 38,19 & 40,63 & $39.073 \mathrm{ab}$ & 2.18 \\
\hline $\mathrm{R}_{3}\left(0,10^{\circ} \%\right.$ OI $)$ & 40,85 & 40,52 & 40.80 & $40,723 \mathrm{bc}$ & 6,50 \\
\hline $\mathrm{R}_{4}(0,15 \%$ OI $)$ & 41,37 & 41,64 & 42,56 & $41,857^{\mathrm{c}}$ & 9,46 \\
\hline $\mathrm{R}_{5}(0.20 \%$ OI $)$ & 41,22 & 44,47 & 42,14 & $42,610^{\mathrm{cd}}$ & 11,43 \\
\hline $\mathrm{R}_{6}(0.25 \%$ OI) & 43.99 & 44,15 & 44,50 & $44,213^{\mathrm{d}}$ & 15,62 \\
\hline $\mathrm{R}_{7}(0.3090$ OI $)$ & 44.20 & 44,07 & 44,30 & $44.190^{\mathrm{d}}$ & 15,56 \\
\hline
\end{tabular}

Keterangan: Nilai rata-rata dengan manuskrip yang berlainan menunjukkan adanya perbedaan yang sangat nyata $(\mathrm{P}<0,01)$.

Penggunaān OI 0,05\% ternyata menghasilkan berat produksi telur per ekor per hari masih sama dengan pada ransum tanpa OI, namun bila penggunaan $\mathrm{Ol}$ naik sebanyak $0,10-0,30 \%$ tampak jelas adanya peningkatan pada berat produksi telur per ekor per hari. Di sini jelas bahwa penggunaan OI sebanyak $0,100 \%-0.30 \%$ dalam ransum akan menaikkan berat produksi telur per ekor setiap harinya, yaitu mulai dari $6,50 \%$ dapat naik terus sampai tak kurang dari $15,509 \%$.

\section{Konversi pakan}

Konversi pakan rata-rata per hari selama 12 minggu dari ketujuh perlakuan ransum ternyata menunjukkan adanya perbedaan $(\mathrm{P}<0,01)$. Semakin tinggi penggunaan OI dari $0,05 \%-0,25 \%$ dalam ransum akan semakin kecil konversi pakan setiap harinya yaitu dari 3,247 dapat turun sampai menjadi 2,797 (tabel 6). Walaupun penggunaan OI $0,05 \%$ masih belum menunjukkan adanya perbedaan pada konversi pakan dengan ransum tanpa OI, begitu pula penggunaan $\mathrm{OI} 0,30 \%$ masih sama dengan yang menggunakan OI $0,25 \%$ namun pada penggunaan $0,10-0,25 \%$ OI tampak jelas adanya perbaikan pada konversi pakan yaitu mulai dari $7.290 \%$ dapat turun terus sampai mencapai $13,85 \%$.

Tabel 6. Konversi pakan setiap hari.

\begin{tabular}{lcccccc}
\hline & \multicolumn{3}{c}{ B lok } & & Turun \\
\cline { 2 - 4 } Perlakuan & 1 & 2 & 3 & Rata-rata & $\begin{array}{c}\text { To } \\
(\%)\end{array}$ \\
\hline $\mathrm{R}_{1}(0 \%$ OI $)$ & 3,35 & 3,28 & 3,11 & $3,247^{\mathrm{a}}$ & $\mathrm{o}$ \\
$\mathrm{R}_{2}(0,05 \%$ OI $)$ & 3,20 & 3,27 & 3,04 & $3,170^{\mathrm{a}}$ & 2,37 \\
$\mathrm{R}_{3}(0,10 \%$ OI $)$ & 2,96 & 3,09 & 2,98 & $3,010^{\mathrm{b}}$ & 7,29 \\
$\mathrm{R}_{4}(0,15 \%$ OI $)$ & 2,98 & 2,87 & 2,80 & $2,883 \mathrm{bc}$ & 11,21 \\
$\mathrm{R}_{5}(0,20 \%$ OI $)$ & 2,98 & 2,77 & 2,83 & $2,860^{\mathrm{bc}}$ & 11,91 \\
$\mathrm{R}_{6}(0,25 \%$ OI $)$ & 2,79 & 2,85 & 2,75 & $2,797^{\mathrm{c}}$ & 13,85 \\
$\mathrm{R}_{7}(0,30 \%$ OI $)$ & 2,78 & 2,88 & 2,82 & $2,829^{\mathrm{c}}$ & 12,87 \\
\hline
\end{tabular}

Keterangan: Nilai rata-rata dengan manuskrip yang berlainan menunjukkan adanya perbedaan yang sangat nyata $(\mathrm{P}<0,01$.) pert

yaitu

guna

ubah

Tabe

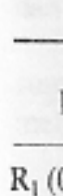

$\mathrm{R}_{1}(0$
$\mathrm{R}_{2}(0$

$R_{2}(0$
$R_{3}(0$

$\mathrm{R}_{4}(0$

$\mathrm{R}_{5}(0$

$\mathrm{R}_{6}(0$

$\mathrm{R}_{7}(0$

Ni

berki

OI $y_{1}$

men:

an te

Kam.

Tabe

$\frac{\mathrm{P}}{\mathrm{R}_{\mathrm{I}}(0}$

$\mathrm{R}_{1}(0$
$\mathrm{R}_{2}(0$

$R_{2}(0$
$\mathrm{R}_{3}(0$

$\mathrm{R}_{4}(0$

$\mathrm{R}_{5}(0$

$\mathrm{R}_{6}(0$

$\mathrm{R}_{7}(0$.

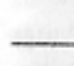

Unit

perlak

bedaa

pun $\mathrm{t}$

mena

meng 


\section{Tebal kerabang}

Tebal kerabang telur rata-rata dari ketujuh ransum perlakuan ternyata tidak menunjukkan adanya perbedaan yaitu berkisar dari $0,348-0,3623 \mathrm{~mm}$ (Tabel 7), jadi penggunaan OI dari $0,05 \%-0,30 \%$ dalam ransum tidak mengubah tebal kerabang telur.

Tabel 7. Tebal kerabang telur $(\mathrm{mm})$

\begin{tabular}{|c|c|c|c|c|}
\hline \multirow{2}{*}{ Periakuan } & \multicolumn{3}{|c|}{$\mathrm{B} 10 \mathrm{k}$} & \multirow{2}{*}{ Rata-rata } \\
\hline & 1 & 2 & 3 & \\
\hline$R_{1}(0 \%$ OI $)$ & 0,351 & 0,360 & 0,349 & 0,353 \\
\hline$R_{2}(0,05 \%$ OI $)$ & 0,357 & 0,344 & 0,360 & 0,353 \\
\hline$R_{3}(0,10 \%$ OI $)$ & 0,341 & 0,356 & 0,346 & 0,348 \\
\hline $\mathrm{R}_{4}(0,15 \%$ OI $)$ & 0,364 & 0,348 & 0,358 & 0,356 \\
\hline $\mathrm{R}_{5}(0,20 \%$ OI $)$ & 0,360 & 0,351 & 0,349 & 0,354 \\
\hline$R_{6}(0,25 \%$ OI $)$ & 0,371 & 0,359 & 0,357 & 0,362 \\
\hline$R_{7}(0,30 \%$ OI $)$ & 0,360 & 0,357 & 0,360 & 0,359 \\
\hline
\end{tabular}

Nilai warna yolk

Nilai warna yolk rata-rata dari ketujuh ransum perakuan ternyata tidak menunjukkan adanya perbedaan yaitu erkisar dari 7,50 - 8,03 (Tabel 8), namun penggunaan DI yang semakin meningkat, dari $0,05-0,25 \%$, cenderung nenaikkan nilai warna yolk, dan nilai ini secara keseluruhin ternyata berada di atas nilai warna yolk yang menurut Kamal dan Murdhike (1983) yaitu sebesar 7,22.

Tabel 8. Nilai warna yolk

\begin{tabular}{ccccc}
\multirow{2}{*}{ Perlakuan } & \multicolumn{3}{c}{ B I ok } & Rata-rata \\
\cline { 2 - 4 } & 1 & 2 & 3 & \\
\hline$R_{1}(0 \%$ OI $)$ & 7,6 & 7,3 & 7,6 & 7,50 \\
$\mathrm{R}_{2}(0,05 \%$ OI $)$ & 7,4 & 7,9 & 7,7 & 7,67 \\
$\mathrm{R}_{3}(0,10 \%$ OI $)$ & 7,3 & 8,1 & 7,6 & 7,67 \\
$\mathrm{R}_{4}(0,15 \%$ OI $)$ & 7,5 & 7,9 & 8,0 & 7,80 \\
$\mathrm{R}_{5}(0,20 \%$ OI $)$ & 7,8 & 8,1 & 7,7 & 7,87 \\
$\mathrm{R}_{6}(0,25 \%$ OI $)$ & 8,5 & 7,9 & 7,7 & 8,03 \\
$\mathrm{R}_{7}(0,30 \%$ OI $)$ & 7,6 & 8,2 & 7,2 & 7,67 \\
& & & & \\
\hline
\end{tabular}

Init Haugh.

Unit Haugh rata-rata selama 12 minggu dari ketujuh erlakuan ransum ternyata tidak menunjukkan adanya peredaan yaitu berkisar dari 82,443 - 86,240 (Tabel 9), walauun begitu penggunaan OI dari $0,05-0,30 \%$ cenderung nenaikkan Unit Haugh bila dibandingkan dengan tanpa enggunakan $\mathrm{OI}$ dalam ransum.
Tabel 9. Nilai Unit Haugh telur.

\begin{tabular}{lcccc}
\hline \multirow{2}{*}{ Perlakuan } & \multicolumn{3}{c}{ B I o k } & Rata-rata \\
\cline { 2 - 4 } & 1 & 2 & 3 & \\
\hline $\mathrm{R}_{1}(0 \%$ OI $)$ & 80,07 & 83,82 & 83,84 & 82,443 \\
$\mathrm{R}_{2}(0,05 \%$ OI $)$ & 80,62 & 88,02 & 84,51 & 84,383 \\
$\mathrm{R}_{3}(0,10 \%$ OI $)$ & 83,19 & 87,79 & 87,74 & 86,240 \\
$\mathrm{R}_{4}(0,15 \%$ OI $)$ & 84,45 & 85,97 & 84,88 & 85,100 \\
$\mathrm{R}_{5}(0,20 \%$ OI $)$ & 87,22 & 83,63 & 84,57 & 85,140 \\
$\mathrm{R}_{6}(0,250 \%$ OI $)$ & 88,08 & 83,57 & 81,16 & 84,270 \\
$\mathrm{R}_{7}(0,30 \%$ OI $)$ & 88,16 & 81,49 & 80,82 & 83,690 \\
& & & & \\
\hline
\end{tabular}

\section{KESIMPULAN}

Dari hasil penelitian tentang penggunaan OI dalam ransum ayam petelur strain Dekalb dapat disimpulkan sebagai berikut : (1). Penggunaan OI dari $0,05 \%-0.30 \%$ ke dalam ransum ayam petelur ternyata tetap dapat mempertahankan : konsumsi pakan, berat telur, tebal kerabang, nilai warna yolk dan nilai Unit Haugh, (2). Penggunaan OI dari $0,10 \%-0,30 \%$ ke dalam ransum ayam petelur ternyata dapat memperbaiki : jumlah produksi telur (naik lebih dari 120 ), berat produksi telur (naik lebih dari $15 \%$ ) dan konversi pakan (turun lebih dari 13\%).

Agar diperoleh hasil yang optimal maka disarankan OI sebaiknya digunakan sebanyak $0,20 \%-0,30 \%$ di dalam ransum ayam petelur.

\section{DAFTAR PUSTAKA}

Anggorodi, R. 1979. Ilmu Makanan Ternak Umum. PT. Gramedia, Jakarta.

Ewing, W.R. 1961. Poultri Nutrition. 4th. ed. W. Ray Ewing Publisher, South Pasadena California, USA.

Gomez. K.A. dan A.A. Gomez. 1984. Statistical Procedures for Agriculural Research. Edisi II. A. Weley-Interscience Publication, John Wiley \& Sons, New York.

Kamal, M. dan M. Murdhike. 1983. Kemungkinan Pemanfaatan Enceng Gondok Sebagai Sumber Konsentrat Protein Daun (leaf protein concentrate). Untuk Penggantu Kedelai Dalam Ransum Ayam. Proyek Pengembangan Ilmu dan Teknologi Depdikbud No. 377/PIT/DPPM/495/1982. Fakultas Peternakan UGM.

NRC. 1977. Nutrient Requirements of Poultry. Number 1. Seventh Edition. National Academy of Sciences. Washington D.C. 